\title{
Neutralizing antibodies in interferon beta treated patients with multiple sclerosis: knowing what to do now
}

\author{
Commentary to: 10.1007/s00415-010-5844-5 "One-year evaluation of factors \\ affecting the biological activity of interferon beta in multiple sclerosis patients" \\ by $S$. Malucchi et al.
}

Til Menge $\cdot$ Hans-Peter Hartung $\cdot$ Bernd C. Kieseier

Published online: 22 February 2011

(C) Springer-Verlag 2011

Longterm treatment of parenterally administered interferon beta (IFNb) is one of the mainstays of multiple sclerosis (MS) therapy [1]. The first trials were conducted in the early 1980s when human fibroblast derived IFNb was administered intrathecally in an open-label fashion [2]. In ten patients treated monthly for 6 months a significant reduction of the annualized relapse rate was noted compared to the relapse rate at baseline. This effect was not observed in ten control patients with MS that, for ethical reasons, did not undergo repeat sham lumbar punctures. This prompted a larger multicentre trial in which again human IFNb purified from cultured fibroblasts was administered intrathecally [3]. After the advent of recombinant techniques to produce larger amounts of IFNb, the first pivotal trial of IFNb-1b administered subcutaneously every other day in 372 patients with relapsing-remitting MS was published in 1993 [4], and the drug was approved by the FDA for use in MS the same year. Since then two additional IFNb-1a products were evaluated in pivotal trials that yielded positive results and have been marketed subsequently [5, 6]. Treatment with IFNb was also shown to delay disease progression and halt disease activity in patients with clinically isolated syndromes [7-9]. This observation along with neuropathological and MR imaging studies emphasized the importance of early diagnosis and treatment initiation of patients [10]. Overall the effect size of the IFNb preparations is comparable and moderate [1] and the effects of these drugs have been proven to be sustained for more than 15 years [11]. Additionally the

T. Menge $\cdot$ H.-P. Hartung $(\varangle) \cdot$ B. C. Kieseier Department of Neurology, Medical Faculty,

Heinrich-Heine-University, Moorenstrasse 5, 40225 Düsseldorf, Germany

e-mail: Hans-Peter.Hartung@uni-duesseldorf.de long-term safety profile of IFNb treatment is excellent $[12,13]$.

However, with a so called biological, i.e. a proteinaceous therapeutic compound, the issue of IFNb immunogenicity is inherent and has remained a matter of debate [14]. Antibodies against IFNb can be detected in up to $47 \%$ of patients undergoing treatment with IFNb (Table 1) [14]. These antibodies are either purely binding, and then termed binding antibodies (BAbs) or inhibit IFNb activity and then termed neutralizing antibodies (NAbs) (Fig. 1). The proportion of NAbs is variable and differs between available IFNb products (table 1) [14]. Once the bioactivity of injected IFNb is blocked by persistent and hightiter NAbs the beneficial clinically detectable treatment effects of IFNb seem to vanish, albeit with a latency of some one to four years. A diminution of the downregulatory effect on MR disease activity becomes apparent earlier, i.e. 6-18 months after development of high titer Nabs. [15]. Immediate negative effects have not been sufficiently demonstrated. It is of note that most analyses were done in a post-hoc fashion on data from trials originally designed and powered to show treatment effects of IFNb rather than detrimental effects of NAbs [16]. Thus, there is ongoing controversy regarding the clinical impact of NAbs on the management of MS patients [17]. Current European guidelines recommend switching therapy in patients with persistently high-titer NAbs with suspected clinical or MRI activity [16, 18]. Importantly, NAbs may also affect endogenous IFNb as cross-reactivity between antibodies against IFNb-1a or IFNb-1b and endogenous, human fibroblast derived IFNb was shown only recently by us [19].

Antibodies to IFNb are measured in a two-step procedure. First, BAbs are detected by standard antibody assays. In a second step the neutralizing capacity of these 
Table 1 Prevalences of NAbs in prospective IFNb treatment trials
NAbs status was determined by CPE unless stated otherwise. NAbs were considered positive if titers $>20 \mathrm{TRU} / \mathrm{mL}$ were measured

s.c. subcutaneously, i.m. intramuscularly, qod every other day, $q$ wk once weekly, t.i.w. three times weekly

\begin{tabular}{|c|c|c|c|}
\hline & $n$ & NAbs positive patients (\%) & References \\
\hline \multicolumn{4}{|l|}{ IFNb-1b s.c. } \\
\hline \multirow[t]{2}{*}{$1.6 \mathrm{MU}$ qod } & 125 & 42 & [4] \\
\hline & & 47 & {$[25]$} \\
\hline \multirow[t]{4}{*}{8.0 MU qod } & 124 & 38 & [4] \\
\hline & & 45 & {$[25]$} \\
\hline & 277 & 32 & {$[26]$} \\
\hline & 69 & 22 & {$[27]$} \\
\hline 8.0 MU qod (MxA assay) & 360 & $23 / 28$ & {$[28,29,38]$} \\
\hline \multicolumn{4}{|l|}{ IFNb-1a s.c. } \\
\hline \multicolumn{4}{|l|}{$22 \mu \mathrm{g}$} \\
\hline q wk & 95 & 5 & {$[30]$} \\
\hline \multirow[t]{2}{*}{ t.i.w. } & $189 / 167$ & 24 & {$[6,31]$} \\
\hline & 209 & 21 & {$[32]$} \\
\hline \multicolumn{4}{|l|}{$44 \mu \mathrm{g}$} \\
\hline q wk & 98 & 16 & {$[30]$} \\
\hline \multirow[t]{5}{*}{ t.i.w. } & $184 / 167$ & $13 / 14$ & {$[6,31]$} \\
\hline & 204 & 15 & [32] \\
\hline & 374 & 27 & {$[33]$} \\
\hline & 336 & 21 & {$[34]$} \\
\hline & 259 & 17 & {$[35]$} \\
\hline \multicolumn{4}{|l|}{ IFNb-1a i.m. } \\
\hline \multirow[t]{4}{*}{$30 \mu \mathrm{g} \mathrm{q} \mathrm{wk}$} & 193 & 2 & [7] \\
\hline & 402 & 2 & {$[36,37]$} \\
\hline & 338 & 2 & {$[34]$} \\
\hline & 67 & 6 & {$[27]$} \\
\hline Assay not known & 150 & 22 & {$[5]$} \\
\hline $60 \mu \mathrm{g} \mathrm{q} \mathrm{wk}$ & 400 & $6 / 5$ & {$[36,37]$} \\
\hline
\end{tabular}

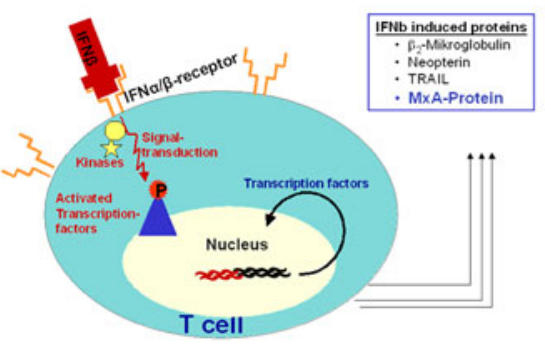

Fig. 1 IFNb-induced signal transduction and possible interferences of anti-IFNb antibodies. Binding of IFNb to its receptor (IFN $\alpha / \beta$ receptor) assembles an active signalling complex resulting in signal transduction through phosphorylation of tyrosine kinases (e.g, Tyk-2, Jak-1). Phosphorylated tyrosine kinases may activate certain transcription factors, that lead to IFNb-mediated gene transcription. Gene translation to proteins, e.g. neopterin, myxovirus resistance protein $\mathrm{A}$ $(\mathrm{MxA})$, results in IFNb-mediated cellular function. BAbs may not

antibodies is demonstrated, for which the in vitro cytopathic effect (CPE) assay can be regarded as the gold standard [20]. Recently it was demonstrated that measuring the mRNA response of the IFNb-induced antiviral MxA interfere with the interaction of IFNb with its receptor, leaving the downstream pathways unaltered (middle panel). In contrast, NAbs hinder the engagement of IFNb with its receptor, thus inhibiting receptor activation. Intracellular downstream responses will not be turned on and IFNb response proteins not be secreted (right panel). Therefore, the assessment of the MxA response either by measuring the MxA protein or its mRNA gene transcript is a sensitive and validated marker for bioactivity of IFNb in humans

protein ex vivo by quantitative PCR yields a good correlate of the bioavailability of IFNb in a given subject $[16,20]$. However, since there are inter-individually different response curves of the MxA mRNA expression, a small 
proportion of patients may be classified false-positively [21-23]. To minimize this potential error it would be ideal to compare individual MxA mRNA responses on IFNb therapy with the respective responses at treatment initiation of the same individual [24].

In this issue of the Journal S. Malucchi et al. have set out to evaluate BAbs and NAbs in 167 patients with MS after 1 year of treatment with IFNb. The proportions of patients treated with either IFNb product were roughly identical. Twenty-two percent of patients showed a pathological, i.e. negative, MxA mRNA response, indicative of reduced bioavailability. Twenty-two of those 37 patients were both positive for BAbs by capture ELISA and for NAbs by CPE; therefore, in these patients the presence of NAbs as detected by CPE resulted in a reduced in vivo bioactivity of IFNb. Eleven of all 167 patients, i.e. 6.6\%, had NAbs at high-titers ( $>100 \mathrm{TRU} / \mathrm{mL})$, ten of these completely abrogated the MxA response. There were also 9.6\% samples with a borderline diminished MxA response. Notably, in three of the $37 \mathrm{MxA}$-negative patients, i.e. in $1.8 \%$ of the entire cohort studied, neither BAbs nor NAbs were detected. The reasons for this may be treatment incompliance, presence of soluble IFNb receptors that capture the injected IFNb [23] or a false-negative result as discussed above.

This study is very helpful and interesting for several reasons and lets us participate in challenging the NAbs issue by one of the leading NAbs research groups in Europe: It demonstrates a good, albeit incomplete, link between the presence of high-titer NAbs (as measured by CPE) and the loss of bioactivity in vivo, and it identifies a small $(\sim 2 \%)$, yet substantial number of patients with loss of IFNb bioactivity not explainable by the presence of NAbs. It is worthwhile to assess these patients in greater detail, as suggested by the authors, given the availability of alternative treatment options, although these may have potential side effects not seen with IFNb. Thus, before switching a patient to glatiramer acetate or escalating the patient to, e.g., natalizumab, a false-negative MxA result and noncompliance should be ruled out. Lastly, this study reproduces independently in a well-defined cohort of patients the frequency of NAbspositivity and high-titer NAbs-positivity after exactly one year of treatment reported earlier. It should be rewarding to follow up those $6.6 \%$ of patients with a reduced, not yet negative MxA responses in order to quantify the in proportion of patients that will eventually completely loose their IFNb bioactivity, i.e. become NAbs positive.

Emergence, frequency and origin of NAbs remain challenging issues while to date consensus seems to have been achieved regarding their immediate impact on IFNb bioactivity and their delayed impact on disease activity. The paper by S. Malucchi et al. does not attempt to settle the matter - a task too vast for one group anyway. But the careful and detailed expert analysis of the antibody status helps to further our understanding of this complicated picture of treatment induced humoral immunity.

Acknowledgments Supported in part by the German Ministry for Education and Research (BMBF), "German Competence Network Multiple Sclerosis (KKNMS)".

Conflict of interest TM has received honoraria and travel support from BayerHealthcare, BiogenIdec, and MerckSerono. HPH and BCK received honoraria for consulting and speaking, with approval by the rector of HHU, from BayerHealthcare, BiogenIdec, MerckSerono, Novartis, Teva Sanofi Aventis. Their department, with approval by the rector of HHU, received unrestricted grants for research on neutralizing antibodies from these companies.

\section{References}

1. Kieseier BC, Hartung HP (2003) Current disease-modifying therapies in multiple sclerosis. Semin Neurol 23:133-146

2. Jacobs L, O'Malley J, Freeman A, Ekes R (1981) Intrathecal interferon reduces exacerbations of multiple sclerosis. Science 214:1026-1028

3. Jacobs L, Salazar AM, Herndon R, Reese PA, Freeman A, Josefowicz R, Cuetter A, Husain F, Smith WA, Ekes R (1986) Multicentre double-blind study of effect of intrathecally administered natural human fibroblast interferon on exacerbations of multiple sclerosis. Lancet 2:1411-1413

4. The IFNB Multiple Sclerosis Study Group (1993) Interferon beta$1 \mathrm{~b}$ is effective in relapsing-remitting multiple sclerosis. I. Clinical results of a multicenter, randomized, double-blind, placebo-controlled trial. Neurology 43:655-661

5. Jacobs LD, Cookfair DL, Rudick RA, Herndon RM, Richert JR, Salazar AM, Fischer JS, Goodkin DE, Granger CV, Simon JH, Alam JJ, Bartoszak DM, Bourdette DN, Braiman J, Brownscheidle CM, Coats ME, Cohan SL, Dougherty DS, Kinkel RP, Mass MK, Munschauer FE III, Priore RL, Pullicino PM, Scherokman BJ, Whitham RH (1996) Intramuscular interferon beta-1a for disease progression in relapsing multiple sclerosis. The Multiple Sclerosis Collaborative Research Group (MSCRG). Ann Neurol 39:285-294

6. PRISMS (Prevention of Relapses, Disability by Interferon beta1a Subcutaneously in Multiple Sclerosis) Study Group (1998) Randomised double-blind placebo-controlled study of interferon beta-1a in relapsing/remitting multiple sclerosis. Lancet 352:1498-1504

7. Jacobs LD, Beck RW, Simon JH, Kinkel RP, Brownscheidle CM, Murray TJ, Simonian NA, Slasor PJ, Sandrock AW (2000) Intramuscular interferon beta-1a therapy initiated during a first demyelinating event in multiple sclerosis. CHAMPS Study Group. N Engl J Med 343:898-904

8. Comi G, Filippi M, Barkhof F, Durelli L, Edan G, Fernandez O, Hartung H, Seeldrayers P, Sorensen PS, Rovaris M, Martinelli V, Hommes OR (2001) Effect of early interferon treatment on conversion to definite multiple sclerosis: a randomised study. Lancet 357:1576-1582

9. Kappos L, Polman CH, Freedman MS, Edan G, Hartung HP, Miller DH, Montalban X, Barkhof F, Bauer L, Jakobs P, Pohl C, Sandbrink R (2006) Treatment with interferon beta-1b delays conversion to clinically definite and McDonald MS in patients with clinically isolated syndromes. Neurology 67:1242-1249

10. Comi G (2009) Shifting the paradigm toward earlier treatment of multiple sclerosis with interferon beta. Clin Ther 31:1142-1157 
11. Carroll WM (2009) Clinical trials of multiple sclerosis therapies: improvements to demonstrate long-term patient benefit. Mult Scler 15:951-958

12. Menge T, Schloot NC, Schott M, Hemmer B, Wiendl H, Roden M, Hartung HP, Kieseier BC (2009) Interferon beta treatment does not induce organ-specific autoantibodies in multiple sclerosis. Neurology 73:900-902

13. Hartung HP (2009) High-dose, high-frequency recombinant interferon beta-1a in the treatment of multiple sclerosis. Expert Opin Pharmacother 10:291-309

14. Hemmer B, Stuve O, Kieseier B, Schellekens H, Hartung HP (2005) Immune response to immunotherapy: the role of neutralising antibodies to interferon beta in the treatment of multiple sclerosis. Lancet Neurol 4:403-412

15. Fox EJ, Vartanian TK, Zamvil SS (2007) The immunogenicity of disease-modifying therapies for multiple sclerosis: clinical implications for neurologists. Neurologist 13:355-362

16. Polman $\mathrm{CH}$, Bertolotto A, Deisenhammer F, Giovannoni G, Hartung HP, Hemmer B, Killestein J, McFarland HF, Oger J, Pachner AR, Petkau J, Reder AT, Reingold SC, Schellekens H, Sorensen PS (2010) Recommendations for clinical use of data on neutralising antibodies to interferon-beta therapy in multiple sclerosis. Lancet Neurol 9:740-750

17. Goodin DS, Frohman EM, Hurwitz B, O'Connor PW, Oger JJ, Reder AT, Stevens JC (2007) Neutralizing antibodies to interferon beta: assessment of their clinical and radiographic impact: an evidence report: report of the Therapeutics and Technology Assessment Subcommittee of the American Academy of Neurology. Neurology 68:977-984

18. Sorensen PS, Deisenhammer F, Duda P, Hohlfeld R, Myhr KM, Palace J, Polman C, Pozzilli C, Ross C (2005) Guidelines on use of anti-IFN-beta antibody measurements in multiple sclerosis: report of an EFNS Task Force on IFN-beta antibodies in multiple sclerosis. Eur J Neurol 12:817-827

19. Sominanda A, Lundkvist M, Fogdell-Hahn A, Hemmer B, Hartung HP, Hillert J, Menge T, Kieseier BC (2010) Inhibition of endogenous interferon beta by neutralizing antibodies against recombinant interferon beta. Arch Neurol 67:1095-1101

20. Hartung HP, Polman C, Bertolotto A, Deisenhammer F, Giovannoni G, Havrdova E, Hemmer B, Hillert J, Kappos L, Kieseier B, Killestein J, Malcus C, Comabella M, Pachner A, Schellekens H, Sellebjerg F, Selmaj K, Sorensen PS (2007) Neutralising antibodies to interferon beta in multiple sclerosis: expert panel report. J Neurol 254:827-837

21. Weinstock-Guttman B, Badgett D, Patrick K, Hartrich L, Santos R, Hall D, Baier M, Feichter J, Ramanathan M (2003) Genomic effects of IFN-beta in multiple sclerosis patients. J Immunol 171:2694-2702

22. Bertolotto A, Sala A, Malucchi S, Marnetto F, Caldano M, Di Sapio A, Capobianco M, Gilli F (2004) Biological activity of interferon betas in patients with multiple sclerosis is affected by treatment regimen and neutralising antibodies. J Neurol Neurosurg Psychiatry 75:1294-1299

23. Gilli F, Marnetto F, Caldano M, Valentino P, Granieri L, Di Sapio A, Capobianco M, Sala A, Malucchi S, Kappos L, Lindberg RL, Bertolotto A (2007) Anti-interferon-beta neutralising activity is not entirely mediated by antibodies. J Neuroimmunol 192:198-205

24. van der Voort LF, Kok A, Visser A, Oudejans CB, Caldano M, Gilli F, Bertolotto A, Polman CH, Killestein J (2009) Interferonbeta bioactivity measurement in multiple sclerosis: feasibility for routine clinical practice. Mult Scler 15:212-218
25. The IFNB Multiple Sclerosis Study Group the University of British Columbia MS/MRI Analysis Group. (1996) Neutralizing antibodies during treatment of multiple sclerosis with interferon beta-1b: experience during the first three years. Neurology 47:889-894

26. Kappos L, Freedman MS, Polman CH, Edan G, Hartung HP, Miller DH, Montalban X, Barkhof F, Radu EW, Bauer L, Dahms S, Lanius V, Pohl C, Sandbrink R (2007) Effect of early versus delayed interferon beta- $1 \mathrm{~b}$ treatment on disability after a first clinical event suggestive of multiple sclerosis: a 3-year follow-up analysis of the BENEFIT study. Lancet 370:389-397

27. Durelli L, Verdun E, Barbero P, Bergui M, Versino E, Ghezzi A, Montanari E, Zaffaroni M (2002) Every-other-day interferon beta- $1 \mathrm{~b}$ versus once-weekly interferon beta- $1 \mathrm{a}$ for multiple sclerosis: results of a 2-year prospective randomised multicentre study (INCOMIN). Lancet 359:1453-1460

28. Panitch H, Miller A, Paty D, Weinshenker B (2004) Interferon beta-1b in secondary progressive MS: results from a 3-year controlled study. Neurology 63:1788-1795

29. European Study Group on interferon beta-1b in secondary progressive MS (1998) Placebo-controlled multicentre randomised trial of interferon beta- $1 \mathrm{~b}$ in treatment of secondary progressive multiple sclerosis. Lancet 352:1491-1497

30. The Once Weekly Interferon for MS Study Group (1999) Evidence of interferon beta-1a dose response in relapsing-remitting MS: the OWIMS Study. Neurology 53:679-686

31. PRISMS Study Group and the University of British Columbia MS/MRI Analysis Group. (2001) PRISMS-4: Long-term efficacy of interferon-beta-1a in relapsing MS. Neurology 56:1628-1636

32. Secondary Progressive Efficacy Clinical Trial of Recombinant Interferon-Beta-1a in MS (SPECTRIMS) Study Group (2001) Randomized controlled trial of interferon- beta-1a in secondary progressive MS: Clinical results. Neurology 56:1496-1504

33. Mikol DD, Barkhof F, Chang P, Coyle PK, Jeffery DR, Schwid SR, Stubinski B, Uitdehaag BM (2008) Comparison of subcutaneous interferon beta-1a with glatiramer acetate in patients with relapsing multiple sclerosis (the REbif vs Glatiramer Acetate in Relapsing MS Disease [REGARD] study): a multicentre, randomised, parallel, open-label trial. Lancet Neurol 7:903-914

34. Panitch H, Goodin DS, Francis G, Chang P, Coyle PK, O'Connor P, Monaghan E, Li D, Weinshenker B (2002) Randomized, comparative study of interferon beta-1a treatment regimens in MS: The EVIDENCE Trial. Neurology 59:1496-1506

35. Giovannoni G, Barbarash O, Casset-Semanaz F, King J, Metz L, Pardo G, Simsarian J, Sorensen PS, Stubinski B (2009) Safety and immunogenicity of a new formulation of interferon beta-1a (Rebif New Formulation) in a Phase IIIb study in patients with relapsing multiple sclerosis: 96-week results. Mult Scler 15:219-228

36. Clanet M, Radue EW, Kappos L, Hartung HP, Hohlfeld R, Sandberg-Wollheim M, Kooijmans-Coutinho MF, Tsao EC, Sandrock AW (2002) A randomized, double-blind, dose-comparison study of weekly interferon beta-1a in relapsing MS. Neurology 59:1507-1517

37. Kappos L, Clanet M, Sandberg-Wollheim M, Radue EW, Hartung HP, Hohlfeld R, Xu J, Bennett D, Sandrock A, Goelz S (2005) Neutralizing antibodies and efficacy of interferon beta-1a: a 4-year controlled study. Neurology 65:40-47

38. Polman C, Kappos L, White R, Dahlke F, Beckmann K, Pozzilli C, Thompson A, Petkau J, Miller D, European Study Group in Interferon Beta-1b in Secondary Progressive MS (2003) Neutralizing antibodies during treatment of secondary progressive MS with interferon beta-1b. Neurology 60:37-43 